\title{
The Effect of Weight Training Using Fast and Slow Repetition Movement Towards Thigh Muscle Hypertrophy
}

\author{
Yendrizal \\ Faculty of Sport Science, Universitas Negeri Padan, Indonesia \\ *Corresponding author. Email: mr.yendrizal@gmail.com

\begin{abstract}
The purpose of the research is to find out the effect of weight training using fast and slow repetition movement towards thigh muscle hypertrophy. This is an experimental research design involving 24 students of FIK UNP who took basketball class as their extra-curricular activities. The instrument used in this study was a thigh muscle hypertrophy test. The data of this study were analyzed using t-test. Based on the results of the data analysis, it was found that: (1) the fast repetition movement training method in weight training affected the hypertrophy of thigh muscle (th $1.988>\mathrm{tt} 1.782$ ); (2) the slow repetition movement training method in weight training also affected the hypertrophy of thigh muscle (th $4.463>$ tt 1.782); and (3) there was a different effect between fast repetition movement training method and slow repetition movement training method on the hypertrophy of thigh muscle (th $1.735>$ tt 1.71). From the result of the research, it can be concluded that slow repetition movement training method more significantly affects the hypertrophy of thigh muscle.
\end{abstract}

Keywords: Weight training, fast and slow repetition, muscle hypertrophy

\section{INTRODUCTION}

Health has a very important role for human life. An unhealthy person leads to decreased quality of life, and vice versa. Exercise is one of the most appropriate ways to maintain health and improve one's physical fitness. In addition, exercise can form a person's body to look proportional. The most suitable exercise to shape one's body is weight training.

Basically, weight training is an exercise by using loads as the media in exercising to achieve certain goals. The loads used in weight training can be the loads coming from within the body itself (Internal Load) and the loads coming from outside the body (External Load). Some forms of weight training by using internal loads are Push Up, Sit Up, Pull Up, Back Up, and so on. On the other hand, some forms of weight training by using external loads are Squat Machine, Leg Extension, Leg Curl, Lunges and so on.

In performing weight training, the body will experience changes as the results of the exercise undertaken, some of which are the increased strength of muscles and the occurrence of muscles growth (Hypertrophy). Accrording to Giriwijoyo and Sidik (2013:209), weight training will lead to the growth of the muscles resulting from: (1) the growth of muscle fibers (muscle hypertrophy), (2) the increasing number of capillaries in the muscle, and (3) the increased connective tissue in the muscle.

Muscle hypertrophy is the increase of contractile elements (actin and myosin) in the muscle, which causes the increase of muscle active strength, the thickening of sarcolemma, and the increase of connective tissue among the muscle fibers, that lead to the increase of muscle passive strength and the growth of muscle tone. According to Fox in Umar (2014: 79), "hypertrophy is the increasing size of muscle fibers as a result of exercise." To conclude, hypertrophy is the increasing size of muscle diameter as a result of the increasing size of muscle fibers.

In addition, Ogasawa et al (2013: 115) in International Journal of Clinical Medicine Vol. 4 mention that as a muscle is overloaded from increased mechanical work, the added stress increases skeletal muscle amino acid transporter expression, which in turn enhances the synthesis of the contractile proteins, actin and myosin. These acute positive balances between muscle protein synthesis (MPS) and muscle protein breakdown (MPB) lead to skeletal muscle hypertrophy 
over time which occurs from both an increase in the thickness and number of myofibrils.

From the description above, it can be concluded that muscles that contract with the heavier loads than before will increase the skeletal muscles to supply acid, which in turn enhance the synthesis of contractile protein, actin and myosin. Muscle Protein Synthesis (MPS) and Muscle Protein Breakdown (MPB) cause the hypertrophy of skeletal muscle over time from both the increase in thickness and the amount of myofibrils.

The phenomenon that occurs nowadays is that most coaches, athletes, and the public do not know which training method is best used for muscle hypertrophy. In doing the exercise, we should have a clear and purposeful aim, meaning that we understand what we want to achieve in the exercise, whether to increase the maximum strength, to reduce the fat level in the body to have a better appearance, to grow the muscles (hypertrophy), to support the activities in other sports, or to enhance the fitness in terms of a combination of the desired shape, the cardiovascular fitness (heart and lung), and so forth. In weight training, there are a variety of training methods that can be applied to get muscle hypertrophy, namely fast reps training method and slow reps training method.

Both the aforesaid weight training methods, i.e. fast reps training method and slow reps training method, have their respective deficiencies and advantages. Therefore, it is necessary to conduct a study of such weight training methods to find out which training method is better for muscle hypertrophy.

\section{METHOD}

This type of study is quasi-experimental in nature. As such, this study examined cause-effect relationship before and after giving the treatment. The design of this treatment comprised the following information. The population of this study was all students registered in 2017 on Faculty of Sport Science who joined KRIDA. Then, the sample of this study was the students registered in 2017 on Faculty of Sport Science who joined basketball class for KRIDA. This study used purposive sampling technique in which the population had to meet certain requirements given by the researcher in order to be the sample of this study. The sample of this study was divided into two weight training groups: fast reps training method group and slow reps training method group. Before being given the treatment, the sample was given pre-test (preliminary test). Then, the sample was given training treatment for 18 meetings. After that, post-test (finaltest) was administered for the sample. The instrument used in this study was a thigh muscle hypertrophy test by measuring the circumference of thigh and the thickness of fat in the thigh. After the data were obtained, they were then converted by using the formula of MMC = MMC-(3.14 x TSF) (caballero et al, 2005: 316). After all the data were collected, they were then compiled and analyzed statistically through the process of analysis requirement test. The data were analyzed by using $t$ test formula. This formula was used to see the difference of mean in both sample groups.

\section{RESULT}

The results revealed that there were significant effects of both training methods on hypertrophy of thigh muscle. It can clearly be seen in the following table.

\begin{tabular}{lccccc}
\hline Trainin & \multicolumn{2}{c}{$\begin{array}{c}\text { Average Score } \\
\text { gre- }\end{array}$} & $\mathbf{t}_{\mathbf{h}}$ & $\mathbf{t}_{\mathbf{t}}$ & Note \\
Group & test & test & & & \\
\hline Fast & 458.14 & 459.83 & 1.98 & 1.78 & Significa \\
Reps & 5 & & 8 & 2 & $\mathrm{nt}$ \\
Trainin & & & & & \\
g & & & & & \\
Method & & & & & \\
Slow & 459.58 & 466.52 & 4.46 & 1.78 & Significa \\
Reps & 1 & 9 & 3 & 2 & nt \\
Trainin & & & & & \\
g & & & & & \\
Method & & & & & \\
\hline
\end{tabular}

As it is seen from the table, there were significant effects of both treatments on thigh muscle hypertrophy of the students registered in 2017 on Faculty of Sport Science at Universitas Negeri Padang. Based on the data presented in the table, there were increasing values in both groups. Regarding the first hypothesis testing, it can be concluded that there was an effect of the first treatment, fast reps training method, on hypertrophy of thigh muscle which can be seen from the values of $t_{h}$ (1.988) which was higher than the value of $t_{t}$ (1.782). Furthermore, regarding the second hypothesis testing, the result revealed that there was an effect of second treatment, slow reps training method, on hypertrophy of thigh muscle. It can be seen from the value of $t_{h}(4.463)$ which was higher that the value of $t_{t}(1.782)$.

According to Guyton and Hall (1997: 1346), hypertrophy can be resulted from: a) the increasing of myofibril as high as hypertrophy, b) the increasing mitochondrial enzymes to $120 \%$, c) the increasing of components of the fostagen in metabolic system including ATP and phosphokreatin to $60 \%-80 \%$, d) the increasing of glycogen reserves to $50 \%$, and e) the increasing of triglyceride reserves (fat) to $75 \%-100 \%$. Because of these changes, the aerobic and anaerobic metabolic systems are increasing; thus, the muscle metabolism is increasing as well and hypertrophy / muscle enlargement resulted.

Based on the aforementioned explanation, it can be said that when the hypertrophy happens, protein synthesis in contractile muscle will be faster than its 
destruction process. Therefore, the amount of actin and myosin filaments will progressively increase in myofibril. Then, myofibril will break in every muscle fiber to form new myofibril. Thus, the increasing amount of new myofibril causes the hypertrophy. The increasing size due to the increasing of actin and myosin filaments in muscle fibers happens as the result of muscle contraction in the maximum strength.

Moreover, the result of the third hypothesis testing can be seen in the following table.

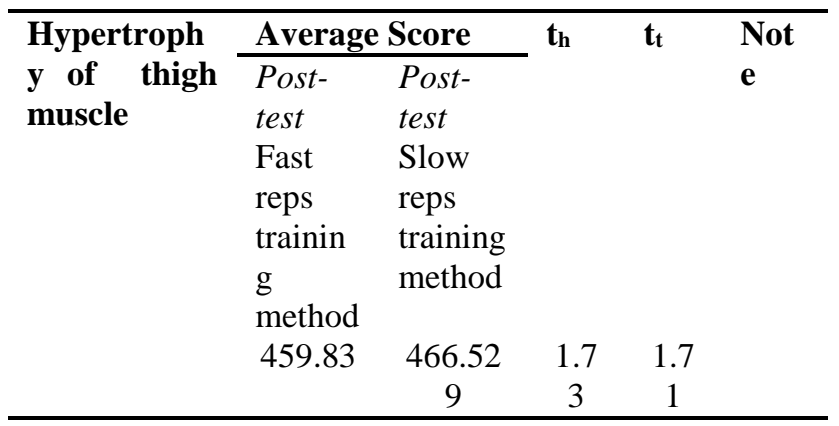

Based on the results presented in the table, there were significant effects of the two methods of training, fast reps training method and slow reps training method, on thigh muscle hypertrophy of the students registered in 2017 on Faculty of Sport Science at Universitas Negeri Padang. It is clearly seen from the hypothesis testing in which the value of $t_{h}$ (1.73) was higher than the value $t_{t}$ (1.71). Besides, the average score of both groups showed that the score of slow reps training method was higher that fast reps training method. Therefore, the slow reps training method gave more significant effect on thigh muscle hypertrophy than fast reps training method.

Slow reps training method is one of the training methods which aims to increase the muscle strength using weight training; thus, it causes big and fast increase on muscle hypertrophy. Besides, the amount of active motor units and the enlargement of muscle fibers generate bigger muscle strength. Furthermore, weight training with slow repetitions gives the challenge to the whole body muscles with heavy weight, without any weight, and with the slow movement frequency which is 3 seconds for contraction and another 3 seconds to go back to the starting pose.

\section{CONCLUSIONS}

The conclusions of this study are as follows. There was an effect of fast reps training method towards thigh muscle hypertrophy of the students registered in 2017 on Faculty of Sport Science at Universitas Negeri Padang. It can be seen from the increasing of average score in pre-test and post-test as much as 1.688 .

There was an effect of slow reps training method towards thigh muscle hypertrophy of the students registered in 2017 on Faculty of Sport Science at
Universitas Negeri Padang. It is shown from the increasing of average score in pre-test and post-test as much as 6. 948 .

There was significant difference of both fast and slow reps training methods. Besides, the slow reps training method affected students' thigh muscle hypertrophy more significantly. It is clearly shown on the increase of average score of both groups in which the slow reps training method's score (6.948) was dramatically higher than fast reps training method's score (1.688).

Based on the above-mentioned findings, both training methods gave the effect on thigh muscle hypertrophy; however, slow reps training method gave more significant effect than fast reps training method. Besides, this method can be used to train every muscle to generate muscle hypertrophy.

\section{REFERENCES}

[1] Caballero, Benjamin. Allen, Lindsay \& Prentice, Andrew. 2005. Encyclopedia of human nutrition. Oxford, UK: Elsevier Academic Press Griwijoyo, Y. S. Santosa, \& Sidik Dikdik Zafar. 2013. Ilmu Faal Olahraga (Fisiologi Olahraga). Bandung: PT Remaja Rosdakarya Bandung.

[2] Guyton \& Hall.Textbook of Medical Physiology 9/E. Fisiologi Kedokteran Edisi 9.Setiawan, Irawati dkk.(terj).1997. Jakarta: Penerbit Buku Kedokteran ECG.

[3] Ogasawara, R et al. (2013). Low-Load Bench Press training To Fatigue Result In Muscle Hypertrophy Similar To High-Load Bench Press Training. International Journal of Clinical Medicine, 4, 114-121.

[4] Umar. 2004. Fisiologi Olahraga. Padang: FIK Universitas Negeri Padang. UNP Press.Apriagus \& Bafirman. 2008. Pembentukan Kondisi Fisik. Padang: FIK Universitas Negeri Padang 